\title{
Sex Differences in Age-Related Decline of Urinary Insulin-Like Growth Factor-Binding Protein-3 Levels in Adult Bonobos and Chimpanzees
}

\author{
Verena Behringer ${ }^{1 *}$, Stefan A. Wudy ${ }^{2}$, Werner F. Blum², Jeroen M. G. Stevens ${ }^{3}$, \\ Thomas Remer ${ }^{4}$, Christophe Boesch ${ }^{1}$ and Gottfried Hohmann ${ }^{1}$ \\ ${ }^{1}$ Department of Primatology, Max Planck Institute for Evolutionary Anthropology, Leipzig, Germany, ${ }^{2}$ Laboratory for \\ Translational Hormone Analytics in Paediatric Endocrinology, Center of Child and Adolescent Medicine, Justus-Liebig- \\ University, Giessen, Germany, ${ }^{3}$ Centre for Research and Conservation, Royal Zoological Society of Antwerp, Antwerp, \\ Belgium, ${ }^{4}$ DONALD Study Dortmund, IEL-Nutritional Epidemiology, University of Bonn, Dortmund, Germany
}

\section{OPEN ACCESS}

Edited by:

Miriam Capri,

University of Bologna, Italy

Reviewed by: Jacques Epelbaum,

French Institute of Health and Medical Research, France James Harper, Sam Houston State University, USA

*Correspondence: Verena Behringer verena_behringer@eva.mpg.de

\footnotetext{
Specialty section:

This article was submitted to

Endocrinology of Aging,

a section of the journal

Frontiers in Endocrinology
}

Received: 17 June 2016 Accepted: 11 August 2016 Published: 23 August 2016

Citation:

Behringer V, Wudy SA, Blum WF Stevens JMG, Remer T, Boesch C and Hohmann G (2016) Sex Differences in Age-Related Decline of

Urinary Insulin-Like Growth Factor-Binding Protein-3 Levels in Adult Bonobos and Chimpanzees. Front. Endocrinol. 7:118. doi: 10.3389/fendo.2016.00118
There is increasing interest in the characterization of normative senescence in humans. To assess to what extent aging patterns in humans are unique, comparative data from closely related species, such as non-human primates, can be very useful. Here, we use data from bonobos and chimpanzees, two closely related species that share a common ancestor with humans, to explore physiological markers that are indicative of aging processes. Many studies on aging in humans focus on the somatotropic axis, consisting of growth hormone (GH), insulin-like growth factors (IGFs), and IGF binding proteins (IGFBPs). In humans, IGFBP-3 levels decline steadily with increasing age. We used urinary IGFBP-3 levels as an alternative endocrine marker for IGF-I to identify the temporal pattern known to be related with age-related changes in cell proliferation, growth, and apoptosis. We measured urinary IGFBP-3 levels in samples from 71 bonobos and 102 chimpanzees. Focusing on samples from individuals aged 10 years or older, we found that urinary IGFBP-3 levels decline in both ape species with increasing age. However, in both species, females start with higher urinary IGFBP-3 levels than males, experience a steeper decline with increasing age, and converge with male levels around the age of 30-35 years. Our measurements of urinary IGFBP-3 levels indicate that bonobos and chimpanzees mirror human patterns of age-related decline in IGFBP-3 in older individuals ( $<10$ years) of both sexes. Moreover, such as humans, both ape species show sex-specific differences in IGFBP-3 levels with females having higher levels than males, a result that correlates with sex differences in life expectancy. Using changes in urinary IGFBP-3 levels as a proxy for changes in GH and IGF-I levels that mark age-related changes in cell proliferation, this approach provides an opportunity to investigate trade-offs in life-history strategies in cross-sectional and in longitudinal studies, both in captivity and in the wild.

Keywords: aging pattern, urinary marker, IGFBP-3, primate, ape species, pan paniscus, pan troglodytes 


\section{INTRODUCTION}

Compared to other non-human primates, human life span is longer and longevity increases progressively in all age classes, which translates into an overall "aging" of the human population. There is an increasing interest in understanding the biological phenomenon of advanced life stages, not only in disease etiology but also in characterizing normative senescence $(1,2)$. Senescence describes the time from full maturity to death and is characterized by a decline of the integrity and function of organic systems, decreased reproduction, and increased mortality $(2,3)$. Ethical and practical issues constrain investigations of such topics in humans to some degree, and data from non-human primates are considered to offer a good alternative model.

Non-human primates have relatively long life expectancies and in most species, individuals experience a phase of life that is characterized by visible signs of senescence (4). Additionally, the time period during which apparently healthy individuals develop alterations in behavior and age-related dysfunctions is longer in non-human primates compared to other animals (2). These two factors make non-human primates particularly interesting for exploring phenotypic traits of human senescence in an evolutionary context.

Like humans, many non-human primate species show consistent sex differences in aging, with adult males having shorter life spans and higher age-specific mortality than adult females (5-7). In captive and wild chimpanzees, females have on average a longer life span than males [e.g., Ref. (8-10)]. In wild bonobos, life expectancy and maximum life span are not yet well known, but life expectancy in captivity tends to be longer in females than in males $(8,11)$. The reasons for the observed sex differences in life expectancy remain to be explored. However, evidence from studies suggests that sex differences in life expectancy may be due to health status and/ or behavioral strategies $(9,12,13)$. Another possible explanation is that the sexes may differ in terms of age-related variation of physiological constitution. The goal of our study is to establish an endocrine marker to investigate aging processes in bonobos and chimpanzees.

Many studies on senescence in humans focused on the somatotropic axis, a multicomponent network consisting of growth hormone (GH), insulin-like growth factors (IGFs), IGF binding proteins (IGFBPs), and IGF receptors and IGFBP proteases (BP-Pr). The components of the somatotropic axis are involved in the regulation of metabolism and somatic growth, as well as proliferation, survival, differentiation, and motility of cells by activating multiple signaling pathways [e.g., Ref. (14-16)].

Growth hormone stimulates cell proliferation and regeneration and is a major endocrine regulator of postnatal growth in mammals (17). Secretion of GH is regulated by negative feedback of serum glucose, free fatty acids, and IGF-I $(18,19)$.

IGF binding proteins are part of the IGF family of growth factors [e.g., Ref. $(20,21)]$. In humans and non-human primates, IGFs exist in two forms, IGF-I and IGF-II (15). Both are synthesized mainly in the liver, and IGF-I increases in response to GH [e.g., Ref. $(22,23)]$. In turn, rising IGF-I levels feedback on the hypothalamus and pituitary and inhibit GH release (24-26).
The secretion of IGF-I is GH dependent (25-27) and, therefore, can serve as a surrogate marker for anabolic $\mathrm{GH}$ activity.

In vitro studies and animal experiments showed synergistic actions of GH and IGF-I on carbohydrate and lipid metabolism [e.g., Ref. $(25,28,29)]$. In addition, IGF-I is antiapoptotic and stimulates cell mitogenesis, survival, differentiation, and somatic growth [e.g., Ref. $(14,15,23)]$. Furthermore, IGF-I acts synergistically with insulin in the postprandial period as a hypoglycemic hormone (15). The amount of circulating IGF-I is determined by its production rate and metabolic clearance, and is modulated by IGFBPs that limit the availability of IGF to the IGF receptor (23). About $1 \%$ of blood IGF-I circulates in its free, unbound form, whereas most circulating IGF-I (about 99\%) is bound to IGFBPs (30).

In humans, six IGFBPs have been identified and constitute an elaborate transport and regulatory system for IGF-I, and IGF-Iindependent actions [e.g., Ref. (31)]. The main carrier for IGF in serum is IGFBP-3. It constitutes over $95 \%$ of the total IGFBP on a molar basis in humans $(16,27)$. IGFBP-3 is synthesized mainly in the liver $(16,28,32)$. Approximately $80 \%$ of IGF-I is bound to IGFBP-3, which then forms a large molecular weight complex with an acid-labile subunit (ALS) [e.g., Ref. $(17,33)$ ]. While the half-life of unbound IGFBP-3 is between 30 and $90 \mathrm{~min}$ and that of free IGF-I is less than $10 \mathrm{~min}$, the half-life of the complex is about $12 \mathrm{~h}(15)$. By extending the serum half-life of IGF-I, IGFBP-3 affects cellular growth and the availability of IGF to receptors $(23,25,34)$. Besides these functions, the complex may serve as an intravascular reservoir of IGFs that has the potential to strengthen or inhibit the activity of IGFs [e.g., Ref. (28, 34-36)]. In addition to the modulatory effect on IGF, IGFBP- 3 induces cell apoptosis and inhibition of proliferation [e.g., Ref. $(14,23,37)]$.

In humans, the somatotropic axis is age dependent (22). Serum IGF-I levels are low in infancy and childhood, then peak during adolescence, and decrease gradually with increasing age [e.g., Ref. $(16,36,38,39)]$. IGFBP-3 levels undergo similar changes: values are low at birth, increase rapidly during the first weeks of life, and more slowly during later stages until they reach their maxima during puberty. From 18 years onward circulating IGFBP-3 levels decline steadily [e.g., Ref. $(15,33,36,40)]$. In adults of both sexes, blood IGF-I levels decrease with age (24), and thereby contribute to age-related pathogenesis (41). Apart from age-related changes, various studies have reported sex-specific differences in IGF-I and IGFBP-3 levels: while average IGF-I and IGFBP-3 levels in elderly humans did not differ (20), IGFBP-3 levels were significantly higher in girls than in boys (38).

From neonates to the elderly, the components of the somatotropic axis are critical for survival [e.g., Ref. (42)]. A reduction in $\mathrm{GH}$ secretion in combination with reduced production of IGF-I contributes to an increase in fat mass and a decrease in muscle tissue (43). A reduction in IGF-I activity is associated with morbidity, increasing risk to develop cardiovascular disease, osteoporosis, and diabetes (29). Other studies have proposed a link between high IGF-I levels and the risk of cancer [e.g., Ref. (44)]. The correlation of age-related changes of IGF-I and IGFBP-3 levels may be due to a decline in GH secretion (43), indicating a causal relationship of the activity of the three components (22). 
The age-related changes associated with an increase of IGF-I levels during puberty in humans have also been found in non-human primates, such as macaques (45-47), baboons (48-50), mandrills (51), gibbons (52), and chimpanzees (53). As in humans, IGFBP-3 values of rhesus macaques and baboons reached their maxima during puberty [e.g., Ref. (45, 48, 54)]. Examining IGF-I levels in adult macaques and baboons showed that in both species, serum IGF-I levels decreased with age (55, 56), which is comparable with the human aging pattern.

In non-human primates, adult serum IGF-I levels of males were $30 \%$ higher than in females in baboons (55), but other studies did not detect such differences in baboons and mangabeys (54, 57). IGF-I levels are higher in young female chimpanzees than in males (53), whereas in baboons and mandrills the opposite was shown $(49,51)$.

Most studies investigating physiological aging patterns in chimpanzees $(58,59)$ focused on topics, such as reproductive senescence (60) and age-related changes of neural structures [e.g., Ref. $(61,62)]$. Moreover, to our knowledge, no study has explored senescence in bonobos, the sister species of chimpanzees. Therefore, the aim of the present study is to use measurements of urinary IGFBP-3 levels from captive adult bonobos and chimpanzees of both sexes to address the following questions: (1) Do urinary IGFBP-3 levels of adult chimpanzees and bonobos gradually decline with age? (2) Do females and males in either species differ in their overall levels of urinary IGFBP-3? (3) Do age-related changes in urinary IGFBP-3 levels of bonobos and chimpanzees reflect the observed sex difference in life expectancy?

When exploring the impact of the somatotropic axis on development, sex, and aging in non-human primates studies used blood samples. Given the ethical constraints imposed by guidelines of animal welfare, there is a need for alternative approaches, based on sample matrices that can be collected non-invasively. Although the IGFBP-3 concentration is approximately three times lower in urine compared to serum $(35,37,63)$, urine IGFBP- 3 measures can be used as a physiological marker to assess GH-IGFs aging patterns in hominoids and other primates. Urinary IGFBP-3 has been measured in urine of healthy humans with Western ligand blots $(35,64)$ and with immunoassay [e.g., Ref. $(63,65)]$. IGFBP-3 levels reflect the GH secretory state, they are significantly correlated with serum IGF-I levels $(27,45,66)$. Using physiological markers that can be extracted from non-invasively collected samples has several advantages. First, they facilitate monitoring age-related changes over time, collection of longitudinal records, construction of life-history profiles, and assessment of fitness (57, 67). Second, the technique can be applied to individuals living in natural environments.

\section{MATERIALS AND METHODS}

We measured IGFBP-3 levels in urine samples collected at random from 71 bonobos ( 31 males, 40 females) and 102 chimpanzees (33 males, 69 females). All samples were collected non-invasively from apes housed in zoo facilities (Table S1 in Supplementary Material) in accordance with the recommendations of the $\mathrm{NIH}$ published standards. Details on the sampling protocol as well as the transport and storage of samples have been published previously (68). In brief, urine samples were collected directly from the urine stream or taken off the ground, only when the individual could be identified and when contamination with feces could be excluded. After, the samples were immediately frozen in the zoo, and transported frozen to the Max Planck Institute for Evolutionary Anthropology in Leipzig, Germany. In order to explore changes in IGFBP-3 levels during advanced life stages, we focused our analyses on individuals of 10 years or older (bonobo age range: $10-55$ years, average: 23 years; chimpanzee age range: 10-49 years, average: 23 years). For 54 of the 71 captive bonobos the exact birthdate was available from the studbook. For the chimpanzees, exact birthdates were available for 81 individuals. For six chimpanzees, only the year and month were known, and for these we set the day of birth to the 15th of the respective month. For the remaining individuals, only the year of birth was known, and in these cases the day of birth was set to June 15th of the respective year ( 12 females and 5 males bonobos, 13 females and 2 males chimpanzees).

\section{Urinary IGFBP-3 Analyses}

Urinary IGFBP-3 concentrations were measured by a radioimmunoassay (RIA) developed for human IGFBP-3 detection (40). For assay validation, urine samples from bonobos and chimpanzees were serially diluted, and dilutions were found to parallel the standard curve (Figure S1 in Supplementary Material). Moreover, urine samples from each species were spiked with $2.5,5$, and $10 \mathrm{ng} / \mathrm{ml}$ human IGFBP-3, respectively. On average, recovery was $111 \pm 8 \%$, ranging from $99.0 \%(2.5 \mathrm{ng} / \mathrm{ml}$ spike $)$ to $122.9 \%$ (5 ng/ml spike). Intra-assay and inter-assay coefficients of variation were $1.9 \%$ and $9.2 \%$, respectively. Based on these results, the RIA was considered to be appropriate for measuring IGFBP-3 concentrations in urine samples of bonobos and chimpanzees.

Urine samples were adjusted for their volume, because the concentration of hormones in urine varies with fluid intake and the hydration status (69). For chimpanzees, it is suggested to correct urine volume using specific gravity (SG) [e.g., Ref. (70)]. SG is the ratio of the density of a urine sample relative to the density of water. We measured SG with a digital handheld refractometer (TEC, Ober-Ramstadt, Germany) and calculated urinary IGFBP-3 (nanogram/milliliter) corrected for SG $(69,71)$. The SG population average in our study was 1.007 .

\section{Statistical Analyses}

A general linear mixed model [GLMM (72)] was used to explore the influence of species, sex, and chronological age on urinary IGFBP-3 levels in bonobos and chimpanzees. The model was run in $\mathrm{R}$ (73) using the function lmer provided in the package lme4 (74).

We used a GLMM to investigate the impact of the predictor variables, i.e., species, sex, age (chronologic age in years), and sampling time (predictors with fixed effects) on the log-transformed response variable: urinary IGFBP-3 levels. The model included these four main effects as well as a three-way interaction between species, sex, and age, and all two-way interactions between them. These interactions were included in the model, because we expected that the age-dependent changes of urinary IGFBP-3 levels may differ between bonobos and chimpanzees and/or 
between males and females of each species, and that the degree of sex differences could be species specific. As a random effect, we included location (the zoo housing a specific individual) to control for a possible influence of relevant animal husbandry conditions of zoos (e.g., diet and group size). Furthermore, we included random slopes of age at sampling time within zoo to keep type I error rates at the nominal level of 5\% (75). Age was square root transformed. The transformed age as well as the time of sample collection (to control for diurnal variation) was $z$-transformed to a mean of zero and a SD of one to achieve comparable estimates (76).

For the model, the required normal distribution and homogeneity of residuals were assessed by visual inspections of a histogram, a q-q plot of the residuals, and by plotting residuals against fitted values. All model assumptions were met. Model stability was tested by excluding zoos one by one, which did not indicate any obvious influence of this random effect. To test for collinearity, we examined Variance Inflation Factors [VIF (77)] using the function vif of the R-package car (78) applied to a standard linear model excluding random effects. These indicated that collinearity was not an obvious issue (maximum VIF: 1.044).

Investigating the significance of the fixed effects species, sex, age, and all their interactions as a whole (79), we compared the full model with a null model, excluding the predictor variables and the interactions, but retaining time of sample collection, the random effect of zoo, as well as the random slopes component, using a likelihood ratio test [Ref. (80); R function "anova"]. The data were bootstrapped 1000 times to obtain parameter coefficients. Significance for all tests was set at the $P=0.05$ level.

Data for reproductive status were only available for female bonobos. To test to what extend female reproductive status (cycling, lactating, and pregnant) affect urinary IGFBP-3 levels, we used a one-way ANOVA. To achieve normal distribution of the response variable, IGFBP-3 levels were log-transformed. This analysis was also conducted in $\mathrm{R}$ using the function anova.

\section{RESULTS}

The full-null model comparison revealed that sex, species, and chronologic age had significant effects on urinary IGFBP-3 levels $\left(\chi^{2}=35.298, \mathrm{df}=7, P<0.001\right)$. The three-way interaction of sex, species, and chronologic age was not significant (estimate $=-0.165, \mathrm{SE}=0.235, z$-value $=-0.703, P=0.485$ ) and was, therefore, excluded from the model. In the reduced model, all two-way interactions were included. The interaction of species with age was not significant, because urinary IGFBP-3 levels in both species showed a similar decrease with age (Figure 1).

All two-way interactions, including species were removed from the model. The interaction of chronologic age with sex showed a trend (Table 1A). Therefore, we ran a second reduced model with the interaction of chronologic age and sex, and species as predictor. The interaction of chronologic age with sex remained a trend (Table 1B), demonstrating that age-related changes in urinary IGFBP-3 levels differ between the sexes (Figure 2).

To further explore this, we built subsets for each sex and ran a second reduced model for each subset without the main effect of sex. In both sexes, urinary IGFBP-3 levels decreased significantly with chronologic age, but the decreasing slope was steeper in females when compared with males (males: estimate $=-0.200, \mathrm{SE}=0.082, z$-value $=-2.433, P=0.018$; females: estimate $=-0.422, \mathrm{SE}=0.068, z$-value $=-6.157, P=<0.001)$ (Figure 3). Moreover, urinary IGFBP-3 levels from females started from a higher level than samples from males and converged with male levels around the age of 30 (Figure 3).

According to this analysis, reproductive status of female bonobos did not affect urinary IGFBP-3 levels $\left(F_{2,37}=0.219\right.$, $P=0.804)$.

\section{DISCUSSION}

Little is known about the process of senescence in chimpanzees and to our knowledge nothing has been published about the topic for bonobos. However, there is consensus that information on aging and senescence from our closest living relatives offers a model to better understand the biological components of aging and senescence in our own species [e.g., Ref. $(1,5,81)$ ]. In this study, we used urinary IGFBP-3 levels as an alternative endocrine marker for IGF-I to identify the temporal pattern known to be related with age-related changes in cell proliferation, growth, and apoptosis. Focusing on samples from individuals aged 10 years or older, we found the following: urinary IGFBP-3 levels decline with increasing age. In both species, females start with higher urinary IGFBP-3 levels than males, experience a steeper decline with increasing age, and converge with male levels around the age of 30 years.

The age-related decrease in urinary IGFBP-3 levels obtained in our study from chimpanzees and bonobos correspond with a significant decline of serum and urinary IGFBP-3 levels with increasing age (after mid-puberty) in humans $(36,64,82,83)$. Given that a decrease with age in serum IGF-I and IGFBP-3 levels is consistent with an age-related decline in $\mathrm{GH}$ secretion in humans (43), we assume that the gradual decline in urinary IGFBP-3 levels in the two ape species indicates a corresponding change of GH and IGF-I levels. The reduced secretion of GH and IGF-I corresponds to the somatopause of humans (20,84), an important determinant in age-related changes in body composition and function $(24,39,85)$.

Our measures of urinary IGFBP-3 levels indicate that bonobos and chimpanzees experience an aging pattern in this biomarker, similar to that of modern humans, and sex-specific differences in IGFBP-3 levels are another trait that the three species share. At 10 years of age, female bonobos and chimpanzees have higher levels of urinary IFGBP-3 and converge with males at 30 years of age. The same sex difference has been reported from several human studies, where average serum IGFBP-3 levels were significantly higher in women than in men [e.g., Ref. $(36,82,83$, $86,87)]$. Data for a quantitative comparison between humans, bonobos, and chimpanzees are not yet available. First, most data from humans are based on serum samples, while our data are from urine samples. Second, species-differences in life time expectancy complicate direct comparison of hormone levels. Third, laboratory methods for measuring IGFBP-3 levels vary across studies. 


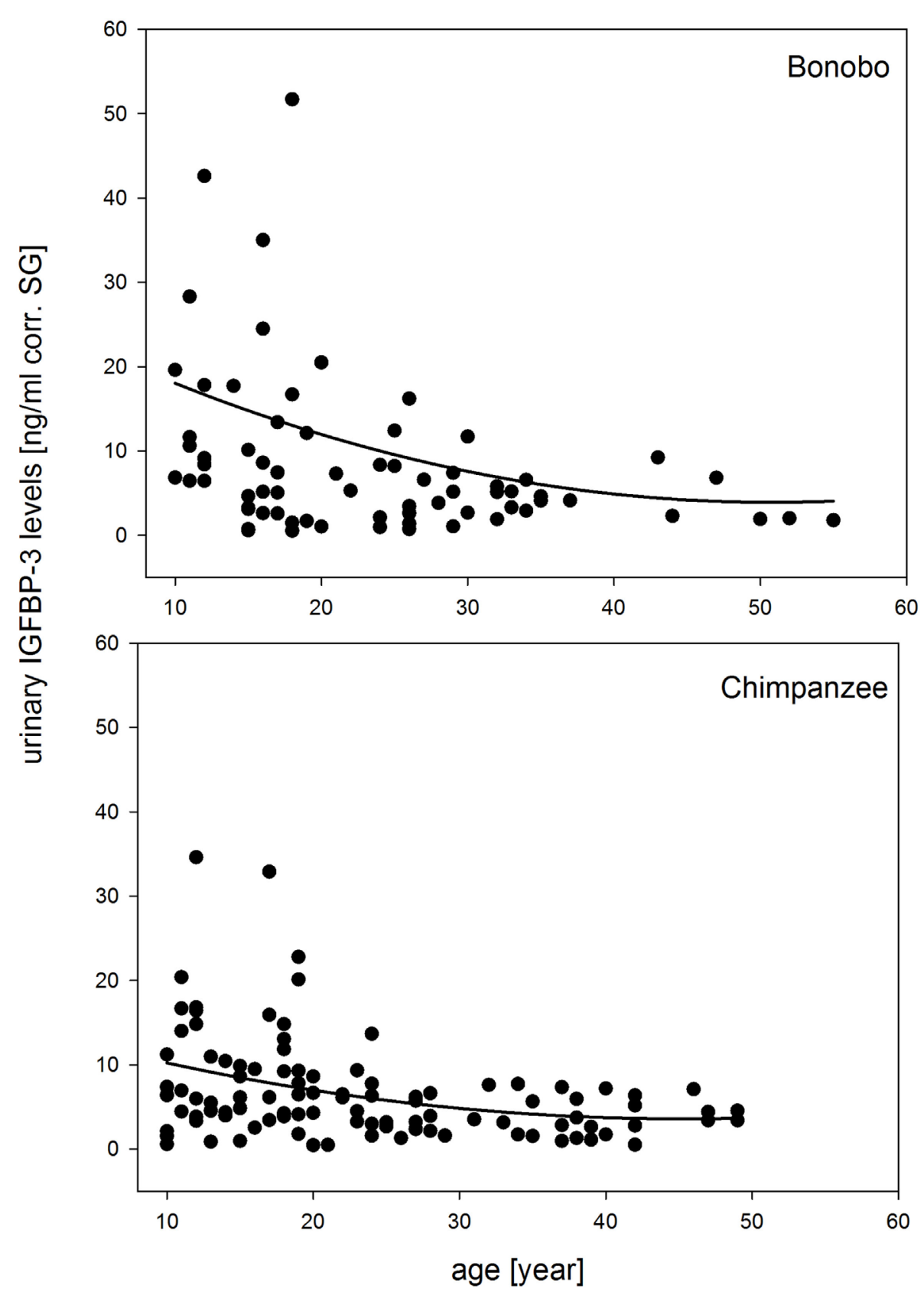

FIGURE 1 | Measures of urinary IGFBP-3 levels corrected for specific gravity (corr. SG) from bonobos (upper plot) and chimpanzees (lower plot) in relation to chronologic age. Sample sizes: $N_{\text {bonobos }}=71$ ( 31 males, 40 females), $N_{\text {chimpanzees }}=102$ ( 33 males, 69 females).

Previous studies have suggested that the decrease in IGFBP-3/ IGF-I levels may indicate progressive senescence in hominids (29). As studies of humans have shown, our study of bonobos and chimpanzees found that the sex-specific decline of IFGBP-3 levels correlates with sex differences in life expectancy. In western human societies, women live on average 5-7 years longer (10\% more) than men (2). In captive apes, females accounted for the majority of individuals older than 40 years. This indicates a greater survivorship in females than males, and resembles the female-biased life expectancy in modern humans $(88,89)$.
The significantly higher IGFBP-3 levels in elderly women correspond with lower bioavailable IGF-I levels, whereas in men, the opposite is the case $(82,83,86,87)$. Therefore, one can speculate that the higher IGFBP-3 levels found in the females of our study reflect lower IGF-I levels. High IGF-I levels may promote the functioning of individual tissues and organs, but have negative pleiotropic effects on longevity as IGF-I is associated with increased oxidative damage and risk of pathology [e.g., Ref. (41, 90)]. In chimpanzees, kidney and liver function decreases significantly with older age. These changes become 
TABLE 1 | Results of the two reduced general linear mixed models obtained by analyzing urinary IGFBP-3 levels from chimpanzees and bonobos of both sexes: (A) with species, chronologic age, and sex in interactions; and (B) with the interaction of sex and chronologic age, and species as fixed effect.

Term Estimate

SE

DF

$x^{2}$

$P$-value

(A) With species, chronologic age, and sex in interactions

Intercept

Time of sample collection

Chronologic age ${ }^{\star}$ sex

Chronologic age*species

Sex*species

\begin{tabular}{rrrrr}
1.826 & 0.129 & & & \\
-0.040 & 0.056 & 1 & 0.501 & 0.479 \\
0.224 & 0.115 & 1 & 3.732 & $\mathbf{0 . 0 5 3}$ \\
-0.068 & 0.107 & 1 & 0.394 & 0.530 \\
0.052 & 0.222 & 1 & 0.056 & 0.813 \\
& & & & \\
1.8211 & 0.119 & & & \\
-0.038 & 0.056 & 1 & 0.457 & 0.499 \\
0.103 & 0.134 & 1 & 0.582 & 0.466 \\
0.223 & 0.115 & 1 & 3.691 & $\mathbf{0 . 0 5 5}$ \\
\hline
\end{tabular}

\section{(B) With the interaction of sex and chronologic age, and species as fixed effect}

Intercept

Time of sample collection

Species

Chronologic age*sex

0.223

0.115

In both models, time of sample collection is a fixed effect and zoo facility is a random effect (*refers to an interaction term and bold numbers indicate significance).
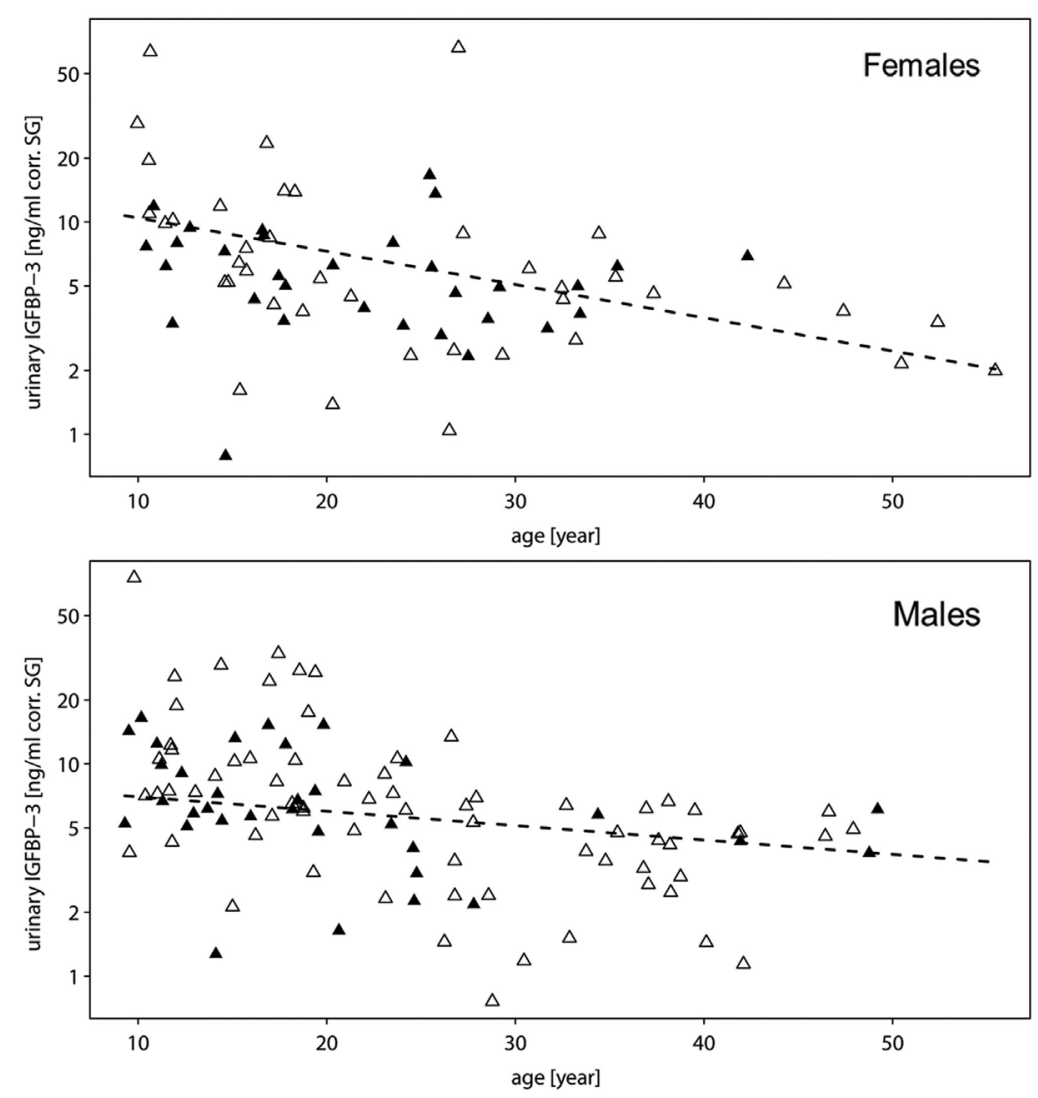

FIGURE 2 | Measures of urinary IGFBP-3 levels corrected for specific gravity (corr. SG) from female (upper plot) and male (lower plot) bonobos (open triangles) and chimpanzees (filled triangles) in relation to chronologic age. The $y$-axis is displayed on a log scale. Sample sizes: $N_{\text {bonobos }}=71$ ( 31 males, 40 females), $N_{\text {chimpanzees }}=102$ (33 males, 69 females).

evident in males around 25-30 years and in females between 30 and 35 years (59). IGFBP-3 is produced by sinusoidal cells (22), and an earlier decrease in liver function in males could be possibly related to lower IGFBP-3 levels.

Another explanation for the sex differences in IGFBP-3 levels could be the relationship between IGFBP-3 and reproduction. First, pregnancy and breastfeeding are associated with increased IGFBP-3 levels in humans $(83,91,92)$ and IGFs are synthesized by the placenta during pregnancy (93). However, in our study, $50 \%$ of the female bonobos (20 individuals) were lactating and $17.5 \%$ (seven individuals) were pregnant, but their urinary IGFBP-3 levels did not differ in comparison to cycling females. Unfortunately, the reproductive status of the female chimpanzees in our study was not sufficiently documented, 


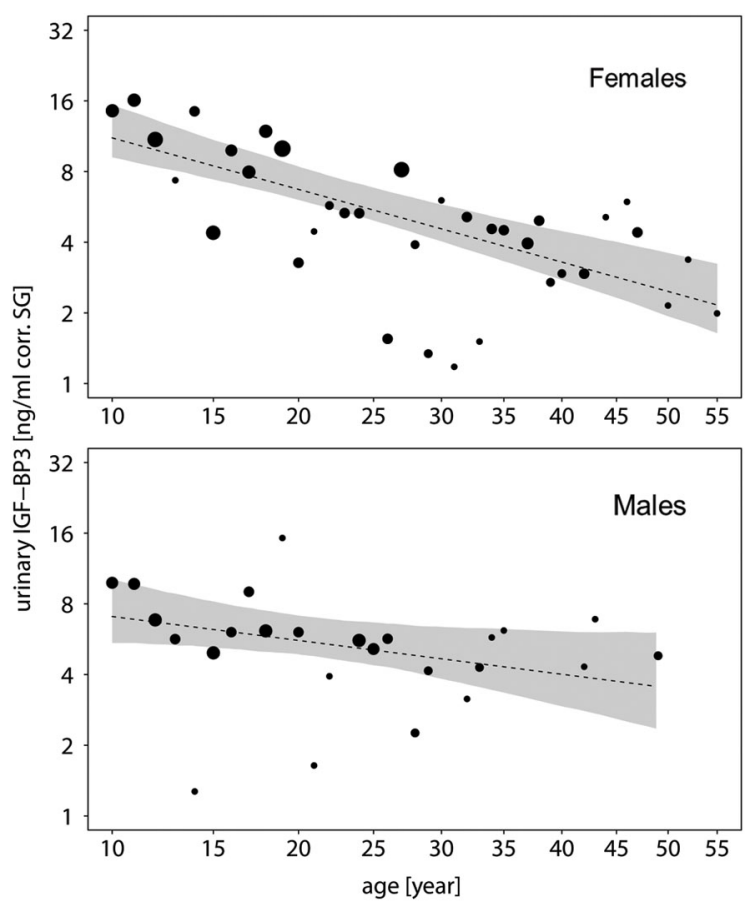

FIGURE 3 | Measures of urinary IGFBP-3 levels corrected for specific gravity (corr. SG) obtained from female (upper plot) and male (lower plot) bonobos and chimpanzees in relation to their chronologic age (year). Shaded areas represent bootstrapped 95\% confidence intervals for expected urinary IGFBP-3 levels. The area of the circles corresponds to the number of individuals. The $y$-axis is displayed on a log scale. Sample sizes: $N_{\text {bonobos }}=71$ (31 males, 40 females), $N_{\text {chimpanzees }}=102$ (33 males, 69 females)

thereby prohibiting us to include this parameter as a confounding factor. Second, IGFs regulate gametogenesis and reproductive function (48). In humans and in captive and wild chimpanzees, birth rates decline at the beginning of the fourth decade of life (94). In women, reproductive senescence is characterized by menopause - a sudden decline in fecundity around 50 years of age [e.g., Ref. (81)]. Although female chimpanzees and bonobos show a similar decline in fecundity at older ages, it is unclear if they experience menopause. However, demographic data from wild and captive chimpanzees indicate that females do experience a post-reproductive period [e.g., Ref. $(12,94,95)]$. In our study, only five female bonobos (12.5\%) and only eight female chimpanzees $(11.6 \%)$ were older than 40 years.

One limitation of our study is its cross-sectional nature, which cannot control for the possible effects of inter-individual variation in development (28). Another limitation is that interventions of management and husbandry are likely to influence hormone levels. However, the advantage of research on captive apes is the exact knowledge of age of the zoo-born individuals, the majority of apes, and their long life expectancy $(1,4)$.

Growth requires input from both, the thyroid axis and the somatotropic axis (96). Thyroid hormones may directly regulate circulating IGFBP-3 levels $(97,98)$. Overall, the age-related decline in urinary IGFBP-3 found in this study corresponds with urinary total triiodothyronine (TT3) changes reported from bonobos and chimpanzees (68). However, the sex difference in urinary IGFBP-3 levels observed in both species was not found in urinary TT3 levels from chimpanzees. By contrast, bonobos show sex differences in both markers, but in opposite directions, with females having significantly higher urinary IGFBP-3 and lower TT3 levels than males. The implication of the different levels in these hormones in males and females on health and longevity could be explored in future long-term data sets.

Because IGFBP-3 levels can be measured in urine samples, this biomarker can be easily used for larger numbers of individuals, thereby overcoming limitations of small sample sizes that are characteristic of invasive sampling techniques $(57,99)$. Moreover, it facilitates collection of repeated measures within individuals to monitor more accurately the process of senescence, which helps to understand the evolutionary theory of it. A central concept in the evolutionary theory of senescence is the idea that aging results from the investment in different life-history trade-offs (100). Therefore, measuring urinary IGFBP-3 levels as a proxy for changes in GH and IGF-I levels and, thus, as a gross estimate of cell proliferation and aging processes, provides an opportunity to investigate trade-offs in life-history strategies in cross-sectional as well as in longitudinal studies both in captivity and in the wild (90).

\section{CONCLUSION}

Using a cross-sectional study design, we found that urinary IGFBP-3 levels decline with age in adult individuals of two closely related ape species, bonobos and chimpanzees. In both species, urinary IGFBP-3 levels of females started at a higher level and had a steeper age-related decline than in males. The age-related and sex-specific changes in urinary IGFBP-3 levels in bonobos and chimpanzees are similar to the patterns observed in modern humans. Moreover, in all three species, the sex-specific decline of IFGBP-3 levels is correlated with sex differences in lifetime expectancy, but in bonobos and chimpanzees, the causal link between lifetime expectancy and IGFBP-3 needs to be explored. Urinary IGFBP-3 levels can be used as an alternative endocrine marker for IGF-I to identify the temporal pattern known to be related with age-related changes in cell proliferation, growth, and apoptosis in bonobos and chimpanzees.

\section{AUTHOR CONTRIBUTIONS}

VB, TR, SW, JS, CB, and GH were involved in the conception and design of the study. VB was responsible for sample collection. WB and SW developed the assay and measured IGFBP-3. VB and $\mathrm{GH}$ analyzed the data. All authors were involved in interpretation of data and writing or editing of this manuscript. All authors approved the final version of the manuscript.

\section{ACKNOWLEDGMENTS}

The sample material analyzed in this study came from the zoo facilities in Aalborg, Amsterdam, Apenheul, Arnhem, Augsburg, Belfast, Berlin, Boras, Bratislava, Bremerhaven, Copenhagen, 
Cologne, Dudley West Midland, Frankfurt, Furuviksparken, Gdansk, Gelsenkirchen, Givskud, Halle, Heidelberg, Kristiansand, Leipzig, Ljubljana, Madrid, Malaga, Milwaukee, Muenster, Munich, Ramat Gan, Planckendael, Romagne, San Diego wild animal park, San Diego zoo, St. André, Stuttgart, Valencia, Verona, Veszprém, Warsaw, and Wuppertal, and the support by the directors and curators is gratefully acknowledged. Special thanks go to the caregivers of the mentioned facilities for collecting urine samples of bonobos and chimpanzees and to the EEP coordinators Frands Carlsen, Tom de Jongh, and Zjef Pereboom for their support. The authors thank Meike Schäfer for technical assistance, Roger Mundry and Franka S. Schaebs for statistical support, and Pamela Heidi Douglas for editing. Caroline Deimel

\section{REFERENCES}

1. Colman RJ, Kemnitz JW. Aging experiments using nonhuman primates. In: Yu BP, editor. Methods in Aging Research. Boca Raton, FL: CRC Press (1999). p. $249-70$.

2. Crews D. Human Senescence Evolutionary and Biocultural Perspectives. Cambridge, UK; New York: Cambridge University Press (2003).

3. Rincon M, Rudin E, Barzilai N. The insulin/IGF-1 signaling in mammals and its relevance to human longevity. Exp Gerontol (2005) 40:873-7. doi:10.1016/j.exger.2005.06.014

4. King F, Yarbrough C, Anderson D, Gordon T, Gould K. Primates. Science (1988) 240:1475-82. doi:10.1126/science.3287624

5. Bronikowski AM, Altmann J, Brockman DK, Cords M, Fedigan LM, Pusey A, et al. Aging in the natural world: comparative data reveal similar mortality patterns across primates. Science (2011) 331:1325-8. doi:10.1126/ science. 1201571

6. Clutton-Brock T, Isvaran K. Sex differences in ageing in natural populations of vertebrates. Proc R Soc B Biol Sci (2007) 274:3097-104. doi:10.1098/ rspb. 2007.1138

7. Gems D. Evolution of sexually dimorphic longevity in humans. Aging (2014) 6:84. doi:10.18632/aging.100640

8. Erwin JM, Hof PR, Ely JJ, Perl DP. One gerontology: advancing understanding of aging through studies of great apes and other primates. In: Erwin JM, Hof PR, editors. Aging in Nonhuman Primates. Basel: Karger (2002). p. 1-21.

9. Hill K, Boesch C, Goodall J, Pusey A, Williams J, Wrangham R. Mortality rates among wild chimpanzees. J Hum Evol (2001) 40:437-50. doi:10.1006/ jhev.2001.0469

10. Muller MN, Wrangham RW. Mortality rates among Kanyawara chimpanzees. J Hum Evol (2014) 66:107-14. doi:10.1016/j.jhevol.2013.10.004

11. Schubert G, Vigilant L, Boesch C, Klenke R, Langergraber K, Mundry R, et al. Co-residence between males and their mothers and grandmothers is more frequent in bonobos than chimpanzees. PLoS One (2013) 8:e83870. doi:10.1371/journal.pone.0083870

12. Nishida T, Corp N, Hamai M, Hasegawa T, Hiraiwa-Hasegawa M, Hosaka K, et al. Demography, female life history, and reproductive profiles among the chimpanzees of Mahale. Am J Primatol (2003) 59:99-121. doi:10.1002/ ajp. 10068

13. Williams JM, Lonsdorf EV, Wilson ML, Schumacher-Stankey J, Goodall J, Pusey AE. Causes of death in the Kasekela chimpanzees of Gombe National Park, Tanzania. Am J Primatol (2008) 70:766-77. doi:10.1002/ajp.20573

14. Baxter RC, Lin M, Martin JL. Stimulation of proliferative pathways by IGFbinding proteins. In: Clemmons D, Robinson ICAF, Christen Y, editors. IGFs: Local Repair and Survival Factors Throughout Life Span. Berlin, Heidelberg: Springer Berlin Heidelberg (2010). p. 59-68.

15. Collett-Solberg PF, Cohen P. Genetics, chemistry, and function of the IGF/ IGFBP system. Endocrine (2000) 12:121-36. doi:10.1385/ENDO:12:2:121

16. Katz L, Lorraine E, Rosenfeld RG, Pinchas S. Clinical significance of insulin-like growth factor binding proteins (IGFBPs). Endocrinologist (1995) 5:36-43. doi:10.1097/00019616-199501000-00006

17. Rosenfeld RG, Hwa V. The growth hormone cascade and its role in mammalian growth. Horm Res (2009) 71:36-40. doi:10.1159/000192434 made very helpful comments on earlier version of this manuscript. We are grateful to the associate editor and the two reviewers for constructive comments on an earlier version of the manuscript. This project was funded by the Max Planck Society.

\section{FUNDING}

This project was funded by the Max Planck Society.

\section{SUPPLEMENTARY MATERIAL}

The Supplementary Material for this article can be found online at http://journal.frontiersin.org/article/10.3389/fendo.2016.00118

18. Olney RC. Regulation of bone mass by growth hormone. Med Pediatr Oncol (2003) 41:228-34. doi:10.1002/mpo.10342

19. Thorner MO, Vance ML, Horvath E, Kovacs K. The anterior pituitary. In: Wilson JD, Foster DW, editors. Williams' Textbook of Endocrinology 2 Philadelphia: W. B. Saunders Co. (1992). p. 228-37.

20. Martin FC, Yeo AL, Sonksen PH. Growth hormone secretion in the elderly: ageing and the somatopause. Baillières Clin Endocrinol Metab (1997) 11:223-50. doi:10.1016/S0950-351X(97)80257-1

21. Rechler MM, Nissley SP. Insulin-like growth factors. In: Sporn IMB, Roberts AB, editors. Peptide Growth Factors and Their Receptors I. Berlin, New York: Springer-Verlag (1991). p. 263-367.

22. Cohen P, Ocrant I, Fielder PJ, Neely EK, Gargosky SE, Deal CI, et al. Insulinlike growth factors (IGFs): implications for aging. Psychoneuroendocrinology (1992) 17:335-42. doi:10.1016/0306-4530(92)90039-A

23. Monzavi R, Cohen P. IGFs and IGFBPs: role in health and disease. Best Pract Res Clin Endocrinol Metab (2002) 16:433-47. doi:10.1053/beem.2002.0212

24. Corpas E, Harman SM, Blackman MR. Human growth hormone and human aging. Endocr Rev (1993) 14:20-39. doi:10.1210/edrv-14-1-20

25. Lamson G, Giudice LC, Rosenfeld RG. Insulin-like growth factor binding proteins: structural and molecular relationships. Growth Factors (1991) 5:19-28. doi:10.3109/08977199109000268

26. Schwander JC, Hauri C, Zapf J, Froesch ER. Synthesis and secretion of insulin-like growth factor and its binding protein by the perfused rat liver: dependence on growth hormone status. Endocrinology (1983) 113:297-305. doi:10.1210/endo-113-1-297

27. Blum WF, Ranke MB. Insulin-like growth factor binding proteins (IGFBPs) with special reference to IGFBP3. Acta Paediatr (1990) 79:55-62. doi:10.111 1/j.1651-2227.1990.tb11634.x

28. Rajaram S, Baylink DJ, Mohan S. Insulin-like growth factor-binding proteins in serum and other biological fluids: regulation and functions. Endocr Rev (1997) 18:801-31. doi:10.1210/er.18.6.801

29. Yang J, Anzo M, Cohen P. Control of aging and longevity by IGF-I signaling. Exp Gerontol (2005) 40:867-72. doi:10.1016/j.exger.2005.08.001

30. Janssen JAMJL, Lamberts SWJ. Is the measurement of free IGF-I more indicative than that of total IGF-I in the evaluation of the biological activity of the GH/IGF-I axis? J Endocrinol Invest (1999) 22:313-5. doi:10.1007/ BF03343563

31. Daughaday WH, Rotwein P. Insulin-like growth factors I and II. Peptide, messenger ribonucleic acid and gene structures, serum, and tissue concentrations. Endocr Rev (1989) 10:68-91. doi:10.1210/edrv-10-1-68

32. Jones JI, Clemmons DR. Insulin-like growth factors and their binding proteins: biological actions. Endocr Rev (1995) 16:3-34. doi:10.1210/ er.16.1.3

33. Baxter RC, Martin JL. Radioimmunoassay of growth hormone-dependent insulinlike growth factor binding protein in human plasma. J Clin Invest (1986) 78:1504-12. doi:10.1172/JCI112742

34. Samani AA, Yakar S, LeRoith D, Brodt P. The role of the IGF system in cancer growth and metastasis: overview and recent insights. Endocr Rev (2007) 28:20-47. doi:10.1210/er.2006-0001

35. Gargosky SE, Pham HM, Wilson KF, Liu F, Giudice LC, Rosenfeld RG. Measurement and characterization of insulin-like growth factor binding 
protein-3 in human biological fluids: discrepancies between radioimmunoassay and ligand blotting. Endocrinology (1992) 131:3051-60. doi:10.1210/ endo.131.6.1280211

36. Janssen JA, Stolk RP, Pols HA, Grobbee DE, de Jong FH, Lamberts SW. Serum free IGF-I, total IGF-I, IGFBP-1 and IGFBP-3 levels in an elderly population: relation to age and sex steroid levels. Clin Endocrinol (Oxf) (1998) 48:471-8. doi:10.1046/j.1365-2265.1998.00300.x

37. Cohen P, Fielder PJ, Hasegawa Y, Frisch H, Giudice LC, Rosenfeld RG. Clinical aspects of insulin-like growth factor binding proteins. Acta Endocrinol (Copenh) (1991) 124(Suppl 2):74-85.

38. Juul A, Dalgaard P, Blum WF, Bang P, Hall K, Michaelsen KF, et al. Serum levels of insulin-like growth factor (IGF)-binding protein-3 (IGFBP-3) in healthy infants, children, and adolescents: the relation to IGF-I, IGF-II, IGFBP-1, IGFBP-2, age, sex, body mass index, and pubertal maturation. J Clin Endocrinol Metab (1995) 80:2534-42. doi:10.1210/jcem.80.8. 7543116

39. Rudman D, Feller AG, Nagraj HS, Gergans GA, Lalitha PY, Goldberg AF, et al. Effects of human growth hormone in men over 60 years old. $N$ Engl J Med (1990) 323:1-6. doi:10.1056/NEJM199007053230101

40. Blum WF, Ranke MB, Kietzmann K, Gauggel E, Zeisel HJ, Bierich JR. A specific radioimmunoassay for the growth hormone (GH)-dependent somatomedin-binding protein: its use for diagnosis of GH deficiency. J Clin Endocrinol Metab (1990) 70:1292-8. doi:10.1210/jcem-70-5-1292

41. Carter CS, Ramsey MM, Sonntag WE. A critical analysis of the role of growth hormone and IGF-1 in aging and lifespan. Trends Genet (2002) 18:295-301. doi:10.1016/S0168-9525(02)02696-3

42. Blum JW, Baumrucker CR. Insulin-like growth factors (IGFs), IGF binding proteins, and other endocrine factors in milk: role in the newborn. In: Bösze Z, editor. Bioactive Components of Milk. New York, NY: Springer New York (2008). p. 397-422.

43. Benbassat CA, Maki KC, Unterman TG. Circulating levels of insulin-like growth factor (IGF) binding protein-1 and -3 in aging men: relationships to insulin, glucose, IGF, and dehydroepiandrosterone sulfate levels and anthropometric measures. J Clin Endocrinol Metab (1997) 82:1484-91. doi:10.1210/ jcem.82.5.3930

44. Renehan AG, Harvie M, Howell A. Insulin-like growth factor (IGF)-I, IGF binding protein-3, and breast cancer risk: eight years on. Endocr Relat Cancer (2006) 13:273-8. doi:10.1677/erc.1.01219

45. Liu F, Powell DR, Styne DM, Hintz RL. Insulin-like growth factors (IGFs) and IGF-binding proteins in the developing rhesus monkey. J Clin Endocrinol Metab (1991) 72:905-11. doi:10.1210/jcem-72-4-905

46. Styne DM. Serum insulin-like growth factor 1 concentrations in the developing rhesus monkey. J Med Primatol (1991) 20:334-7.

47. Suzuki T, Sasano H, Takeyama J, Kaneko C, Freije WA, Carr BR, et al. Developmental changes in steroidogenic enzymes in human postnatal adrenal cortex: immunohistochemical studies. Clin Endocrinol (Oxf) (2000) 53:739-47. doi:10.1046/j.1365-2265.2000.01144.x

48. Bernstein RM, Drought H, Phillips-Conroy JE, Jolly CJ. Hormonal correlates of divergent growth trajectories in wild male anubis (Papio anubis) and hamadryas (P. hamadryas) baboons in the Awash River Valley, Ethiopia. Int J Primatol (2013) 34:732-51. doi:10.1007/s10764-013-9692-x

49. Copeland KC, Kuehl TJ, Castracane VD. Pubertal endocrinology of the baboon: elevated somatomedin-c/insulin-like growth factor I at puberty. J Clin Endocrinol Metab (1982) 55:1198-201. doi:10.1210/jcem-55-6-1198

50. Crawford BA, Handelsman DJ. Androgens regulate circulating levels of insulin-like growth factor (IGF)-I and IGF binding protein-3 during puberty in male baboons. JClin Endocrinol Metab (1996) 81:65-72. doi:10.1210/ jcem.81.1.8550796

51. Bernstein RM, Setchell JM, Verrier D, Knapp LA. Maternal effects and the endocrine regulation of mandrill growth. Am J Primatol (2012) 74:890-900. doi:10.1002/ajp.22038

52. Suzuki J, Kato A, Maeda N, Hashimoto C, Uchikoshi M, Mizutani T, et al. Plasma insulin-like growth factor-I, testosterone and morphological changes in the growth of captive agile gibbons (Hylobates agilis) from birth to adolescence. Primates (2003) 44:273-80. doi:10.1007/s10329-003-0044-x

53. Copeland KC, Eichberg JW, Parker CR, Bartke A. Puberty in the chimpanzee: somatomedin-C and its relationship to somatic growth and steroid hormone concentrations. JClin Endocrinol Metab (1985) 60:1154-60. doi:10.1210/ jcem-60-6-1154

54. Crawford BA, Harewood WJ, Handelsman DJ. Growth and hormone characteristics of pubertal development in the hamadryas baboon. J Med Primatol (1997) 26:153-63. doi:10.1111/j.1600-0684.1997.tb00047.x

55. Willis EL, Wolf RF, White GL, McFarlane D. Age- and gender-associated changes in the concentrations of serum TGF-1 1 , DHEA-S and IGF-1 in healthy captive baboons (Papio hamadryas anubis). Gen Comp Endocrinol (2013) 195:21-7. doi:10.1016/j.ygcen.2013.10.004

56. Woller MJ, Everson-Binotto G, Nichols E, Acheson A, Keen KL, Bowers CY, et al. Aging-related changes in release of growth hormone and luteinizing hormone in female rhesus monkeys. JClin Endocrinol Metab (2002) 87:5160-7. doi:10.1210/jc.2002-020659

57. Bernstein RM, Leigh SR, Donovan SM, Monaco MH. Hormonal correlates of ontogeny in baboons (Papio hamadryas anubis) and mangabeys (Cercocebus atys). Am J Phys Anthropol (2008) 136:156-68. doi:10.1002/ajpa.20791

58. Herndon JG, Tigges J. Hematologic and blood biochemical variables of captive chimpanzees: cross-sectional and longitudinal analyses. Comp Med (2001) 51:60-9.

59. Videan EN, Fritz J, Murphy J. Effects of aging on hematology and serum clinical chemistry in chimpanzees (Pan troglodytes). Am J Primatol (2008) 70:327-38. doi:10.1002/ajp.20494

60. Videan EN, Fritz J, Heward CB, Murphy J. The effects of aging on hormone and reproductive cycles in female chimpanzees (Pan troglodytes). Comp Med (2006) 56:291-9.

61. Gilissen EP, Leroy K, Yilmaz Z, Kövari E, Bouras C, Boom A, et al. A neuronal aging pattern unique to humans and common chimpanzees. Brain Struct Funct (2016) 221:647-64. doi:10.1007/s00429-014-0931-5

62. Sherwood CC, Gordon AD, Allen JS, Phillips KA, Erwin JM, Hof PR, et al. Aging of the cerebral cortex differs between humans and chimpanzees. Proc Natl Acad Sci (2011) 108:13029-34. doi:10.1073/pnas.1016709108

63. Hasegawa Y, Cohen P, Yorgin P, Rosenfeld RG. Characterization of urinary insulin-like growth factor binding proteins. J Clin Endocrinol Metab (1992) 74:830-5. doi:10.1210/jc.74.4.830

64. Gargosky SE, Hasegawa T, Tapanainen P, MacGillivray M, Hasegawa Y, Rosenfeld RG. Urinary insulin-like growth factors (IGF) and IGF-binding proteins in normal subjects, growth hormone deficiency, and renal disease. JClin Endocrinol Metab (1993) 76:1631-7. doi:10.1210/jc.76. 6.1631

65. Zumkeller W, Hall K. Immunoreactive insulin-like growth factor II in urine. Eur J Endocrinol (1990) 123:499-503. doi:10.1530/acta.0.1230499

66. Blum WF, Albertsson-Wikland K, Rosberg S, Ranke MB. Serum levels of insulin-like growth factor I (IGF-I) and IGF binding protein 3 reflect spontaneous growth hormone secretion. J Clin Endocrinol Metab (1993) 76:1610-6. doi:10.1210/jcem.76.6.7684744

67. Leigh SR, Shea BT. Ontogeny of body size variation in African apes. Am J Phys Anthropol (1996) 99:43-65. doi:10.1002/(SICI)1096-8644(199601) 99:1<43::AID-AJPA3>3.0.CO;2-0

68. Behringer V, Deschner T, Murtagh R, Stevens JMG, Hohmann G. Age-related changes in thyroid hormone levels of bonobos and chimpanzees indicate heterochrony in development. J Hum Evol (2014) 66:83-8. doi:10.1016/j. jhevol.2013.09.008

69. Miller RC, Brindle E, Holman DJ, Shofer J, Klein NA, Soules MR, et al. Comparison of specific gravity and creatinine for normalizing urinary reproductive hormone concentrations. Clin Chem (2004) 50:924-32. doi:10.1373/ clinchem.2004.032292

70. Emery Thompson M, Muller MN, Wrangham RW. Technical note: variation in muscle mass in wild chimpanzees: application of a modified urinary creatinine method. Am J Phys Anthropol (2012) 149:622-7. doi:10.1002/ajpa.22157

71. Suwazono Y, Åkesson A, Alfvén T, Järup L, Vahter M. Creatinine versus specific gravity-adjusted urinary cadmium concentrations. Biomarkers (2005) 10:117-26. doi:10.1080/13547500500159001

72. Baayen RH. Analyzing Linguistic Data. Cambridge, UK; New York: Cambridge University Press (2008).

73. R Development Core Team. R: a language and environment for statistical computing. R Foundation for Statistical Computing. Vienna, Austria (2016). Available from: http://www.R-project.org 
74. Bates D, Maechler M, Bolker B, Walker S. Fitting linear mixed-effects models using lme4. J Stat Soft (2013) 67(1):1-48. doi:10.18637/jss.v067.i01

75. Barr DJ, Levy R, Scheepers C, Tily HJ. Random effects structure for confirmatory hypothesis testing: keep it maximal. J Mem Lang (2013) 68:255-78. doi:10.1016/j.jml.2012.11.001

76. Schielzeth H. Simple means to improve the interpretability of regression coefficients. Methods Ecol Evol (2010) 1:103-13. doi:10.1111/j.2041-210X. 2010.00012.x

77. Field AP. Discovering Statistics Using SPSS. 3rd ed. Los Angeles: SAGE Publications (2009).

78. Fox J. An R Companion to Applied Regression. 2nd ed. Thousand Oaks, CA: SAGE Publications (2011).

79. Forstmeier W, Schielzeth H. Cryptic multiple hypotheses testing in linear models: overestimated effect sizes and the winner's curse. Behav Ecol Sociobiol (2011) 65:47-55. doi:10.1007/s00265-010-1038-5

80. Dobson AJ, Barnett AG. An Introduction to Generalized Linear Models. 3rd ed. Boca Raton: CRC Press (2008).

81. Ward EJ, Parsons K, Holmes EE, Balcomb KC, Ford JK. The role of menopause and reproductive senescence in a long-lived social mammal. Front Zool (2009) 6:4. doi:10.1186/1742-9994-6-4

82. DeLellis K, Rinaldi S, Kaaks RJ, Kolonel LN, Henderson B, Le Marchand L. Dietary and lifestyle correlates of plasma insulin-like growth factor-I (IGF-I) and IGF binding protein-3 (IGFBP-3): the multiethnic cohort. Cancer Epidemiol Biomarkers Prev (2004) 13:1444-51.

83. Probst-Hensch NM, Wang H, Goh VH, Seow A, Lee H-P, Mimi CY. Determinants of circulating insulin-like growth factor I and insulin-like growth factor binding protein 3 concentrations in a cohort of Singapore men and women. Cancer Epidemiol Biomarkers Prev (2003) 12:739-46.

84. Junnila RK, List EO, Berryman DE, Murrey JW, Kopchick JJ. The GH/ IGF-1 axis in ageing and longevity. Nat Rev Endocrinol (2013) 9:366-76. doi:10.1038/nrendo.2013.67

85. Rudman D. Growth hormone, body composition, and aging. J Am Geriatr Soc (1985) 33:800-7. doi:10.1111/j.1532-5415.1985.tb04195.x

86. Kaklamani VG, Linos A, Kaklamani E, Markaki I, Mantzoros C. Age, sex, and smoking are predictors of circulating insulin-like growth factor 1 and insulin-like growth factor-binding protein 3. J Clin Oncol (1999) 17:813-813.

87. Schoen RE, Schragin J, Weissfeld JL, Thaete FL, Evans RW, Rosen CJ, et al. Lack of association between adipose tissue distribution and IGF-1 and IGFBP-3 in men and women. Cancer Epidemiol Biomarkers Prev (2002) 11:581-6.

88. Erwin JM, Bloomsmith M, Boysen ST, Hof PR, Holloway R, Lowenstine L, et al. The great ape aging project: a resource for comparative study of behavior, cognition, health, and neurobiology. In: Galdikas BMF, editor. African Apes Chapter 13. New York: Kluwer Academic (2001). p. 195-200.

89. Littleton J. Fifty years of chimpanzee demography at Taronga Park Zoo. Am J Primatol (2005) 67:281-98. doi:10.1002/ajp.20185

90. Monaghan P, Charmantier A, Nussey DH, Ricklefs RE. The evolutionary ecology of senescence. Funct Ecol (2008) 22:371-8. doi:10.1111/j.13652435.2008.01418.x

91. Langford KS, Nicolaides KH, Jones J, Abbas A, McGregor AM, Miell JP. Serum insulin-like growth factor-binding protein-3 (IGFBP-3) levels and IGFBP-3 protease activity in normal, abnormal, and multiple human pregnancy. J Clin Endocrinol Metab (1995) 80:21-7. doi:10.1210/jcem.80.1.7530257

92. Suikkari AM, Baxter RC. Insulin-like growth factor-binding protein-3 is functionally normal in pregnancy serum. J Clin Endocrinol Metab (1992) 74:177-83. doi:10.1210/jcem.74.1.1370163

93. Rutherford JN. Fetal signaling through placental structure and endocrine function: illustrations and implications from a nonhuman primate model. Am J Hum Biol (2009) 21:745-53. doi:10.1002/ajhb.20923

94. Emery Thompson M, Jones JH, Pusey AE, Brewer-Marsden S, Goodall J, Marsden D, et al. Aging and fertility patterns in wild chimpanzees provide insights into the evolution of menopause. Curr Biol (2007) 17:2150-6. doi:10.1016/j.cub.2007.11.033

95. Hiraiwa-Hasegawa M, Hasegawa T, Nishida T. Demographic study of a large-sized unit-group of chimpanzees in the Mahale mountains, Tanzania: a preliminary report. Primates (1984) 25:401-13. doi:10.1007/BF02381663

96. Näntö-Salonen K, Muller HL, Hoffman AR, Vu TH, Rosenfeld RG. Mechanisms of thyroid hormone action on the insulin-like growth factor system: all thyroid hormone effects are not growth hormone mediated. Endocrinology (1993) 132:781-8. doi:10.1210/endo.132.2. 7678799

97. Clemmons DR. Insulin-like growth factor binding proteins and their role in controlling IGF actions. Cytokine Growth Factor Rev (1997) 8:45-62. doi:10.1016/S1359-6101(96)00053-6

98. Seck T, Englaro P, Blum WF, Scheidt-Nave C, Rascher W, Ziegler R, et al. Leptin concentrations in serum from a randomly recruited sample of 50-to 80-year-old men and women: positive association with plasma insulin-like growth factors (IGFs) and IGF-binding protein-3 in lean, but not in obese, individuals. Eur J Endocrinol (1998) 138:70-5. doi:10.1530/eje. 0.1380070

99. Hamada Y, Udono T. Longitudinal analysis of length growth in the chimpanzee (Pan troglodytes). Am J Phys Anthropol (2002) 118:268-84. doi:10.1002/ ajpa. 10078

100. Kirkwood TBL, Westendorp RGJ. Human longevity at the cost of reproductive success: trade-offs in the life history. In: Robine JM, Kirkwood TBL, Allard M, editors. Sex and Longevity: Sexuality, Gender, Reproduction, Parenthood. Berlin, Heidelberg: Springer Berlin Heidelberg (2001). p. 1-6. Available from: http://link.springer.com/10.1007/978-3-642-59558-5_1

Conflict of Interest Statement: No authors (or their institutions) of this manuscript received payment or services from a third party for any aspect of this manuscript. The research was conducted in the absence of any commercial or financial relationships that could be construed as a potential conflict of interest. We do not have patents or copyrights to declare.

Copyright (c) 2016 Behringer, Wudy, Blum, Stevens, Remer, Boesch and Hohmann. This is an open-access article distributed under the terms of the Creative Commons Attribution License (CC BY). The use, distribution or reproduction in other forums is permitted, provided the original author(s) or licensor are credited and that the original publication in this journal is cited, in accordance with accepted academic practice. No use, distribution or reproduction is permitted which does not comply with these terms. 